\title{
Müzik Öğretmeni Adaylarının Benimsedikleri Ĕ̈itim Felsefelerinin Çeşitli Değişkenler Açısından İncelenmesi ${ }^{I}$
}

\author{
Tuba YOKUŞ \\ Muğla Sttkı Koçman Üniversitesi Eğitim Fakültesi \\ E-mail: tubayokus@mu.edu.tr
}

Özet

Bu araştırmanın amacı müzik öğretmeni adaylarının benimsedikleri eğitim felsefelerini belirlemek ve çeşitli değişkenler açısından irdelemektir. Araştırmanın çalışma grubunu 2015- 2016 eğitim-öğretim yılında Muğla Sıtkı Koçman Üniversitesi Ĕgitim Fakültesi Müzik Öğretmenliği Anabilim Dalında öğrenim gören müzik ögretmeni adayları oluşturmaktadır. Araştırmada veri toplama aracı olarak müzik öğretmeni adaylarının eğitim felsefelerini belirlemek için Wiles ve Bondi (1993) tarafindan geliştirilen Doğanay ve Sarı (2003) tarafindan Türkçeye uyarlanan "Felsefi Tercih Değerlendirme" ölçeği kullanılmuştır. Demografik özellikleri ile ilgili bilgi toplamak için ise araştırmacı tarafindan hazırlanan Kişisel Bilgi Formu kullanılmıştır. Araştırmadan elde edilen veriler SPSS Paket programında (\%) yüzde, standart sapma, aritmetik ortalama "Tek Faktörlü Anova" ve "Iiliskisiz Grup t Testi", gibi istatistik analizlerle değerlendirilmiştir. Araştırma sonucunda müzik öğretmeni adaylarının en çok benimsedikleri eğitim felsefesinin "deneyselcilik" olduğu belirlenmiştir. Buna ek olarak mezun olunan okul türü açısından "daimicilik" alt faktöründe anlaml bir farklllık olduğu saptanmış; cinsiyet ve sinıf değişkenleri açısından ise istatistiksel olarak anlamlı bir farklllık belirlenememiştir.

Anahtar kelimeler: Ĕ̆itim felsefesi, felsefe, müzik öğretmeni adayları

\section{An Examination of Philosophy of Education Music Teacher Candidates Adopt in Terms of Different Variables}

\begin{abstract}
This study aims to determine educational philosophy adopted by music teacher candidates and to examine in terms of different variables. The sample for the study consist of music teacher candidates who were enrolled in Muğla Sitkı Koçman University Faculty of Education, Department of Music Teaching in 2015- 2016 academic year. For the data collection, "Philosophy Preference Assessment Scale” by Wiles and Bondi (1993), which was adapted to Turkish by Doğanay and Sarl (2003), is used in order to determine music teacher candidates" educational philosophies. "Personal Information Form", developed by the researcher, is used in order to collect data about the demographics of the music teacher candidates. The data obtained were analyzed by using SPSS program and percentage, standard deviation, mean "Single Factor ANOVA" and the "Independent Group t Test" statistics were run. The results showed that "experimentalism" was the most widely adopted by music teacher candidates. Additionally, a significant difference was found between type of school and "perennialism"
\end{abstract}

\footnotetext{
${ }^{1}$ Bu araştırmada elde edilen bulguların tamamı 12-14 Kasım 2015 tarihleri arasından düzenlenen "Felsefe, Eğitim ve Bilim Tarihi” adlı sempozyumda sözlü bildiri olarak sunulmuştur.
} 
sub-factor. However, a statistically significant difference was not found between gender and class variables.

Keywords: Philosophy of education, philosophy, music teacher candidates

\section{Giriş}

Felsefe, bilgelik sevgisi demektir ve gerçeği bir bütün olarak her yönü ile araştırmaktır. Felsefe aynı zamanda evrensel bir "bilim"dir; gerçeğin bütününü, en son ve asli temellerini araştırır (Ergün, 2014). Bir etkinlik alanı olarak ise felsefe, insana doğru görebilme ve doğru düşünebilme gücü kazandırır. (Timuçin, 2005). Dolayısıyla felsefenin yaşamın tüm alanlarında var olan ya da olması gereken bir etkinlik olduğu söylenebilir. Felsefi bilgi, dünyaya ve olaylara bakış açısını değiştirir. İnsanı olgunlaştırır ve hoşgörü kazandırır. Toplumsal yaşam içerisinde başka insanlarla iletişim kurma, onları anlama ve sorunlarını paylaşmada daha olgun davranışlar sergilemeye yardımcı olur (Karslı, 2007).

Felsefe her bilimle bağlantı kurduğu gibi, her bilim de felsefe ile bağlantı kurmak zorundadır. Eğitim de, bilimler içinde gerek uygulamalarında gerekse teorik zemininin oluşturulmasında felsefe ile en çok ilişki kuran bilimdir (Ergün, 2003). Felsefe ve eğitim birbirlerinin aracı ve amacı, aynı zamanda süreç ve ürünüdür. Eğitim felsefesi bu derin düşünme ve edimsel eylemin bütünleşmesiyle tanımlanabilir (Brauner ve Burns, 1965). Eğitim felsefesi, eğitimi engelleyen sorunları, eğitime yön veren kavram, düşünce ve ilkeleri açıklamaya çalışmaktadır (Ergün,2014). Eğitim bir bakıma felsefenin uygulama alanıdır ve uygulamadan elde edilenlerle, felsefe kendini düzeltip geliştirebilir. Ayrıca, eğitim yeni ve bilimsel bilgiyi sunarak da felsefenin gelişmesine, onda yeni alanların oluşmasına olanak tanır (Kaygısız, 1997). Bireylerin eğitim sürecine ilişkin felsefi tercihleri bir bakıma benimsedikleri eğitim felsefelerinin göstergesidir (Büyükdüvenci, 1987).

İlgili literatürde eğitime yönelik felsefi yaklaşımların farklı şekillerde ele alındığı görülmektedir. (Örn.; Çoban, 2002; Demirel, 2010; Kaygısı1, 1997; Yılmaz, Altınkurt ve Çokluk, 2011). Bununla birlikte, eğitim uygulamalarının kaynağını oluşturan felsefi akımlar genel felsefi akımların doğrultusunda ortaya çıkmıştır. Örneğin; daimicilik ve esasicilik kaynağını idealizm ve realizmden alır. İlerlemecilik ve yeniden kurmacılık ise pragmatik felsefenin eğitime uygulanışıdır. İdealist görüş, gerçekçiliği ruhsal sayan bir felsefe öğretisidir ve gerçeğe giden yolun sadece bilimsel yöntem olduğunu kabul etmez; sezgisel düşüncenin de bilimsel tutum kadar önemli olduğunu savunur (Demirel, 2010). Realizmde ise obje esastır. Bu akım maddeyi gerçek olarak kabul eder (Tozlu, 2002). Diğer taraftan, pragmatik felsefe, gerçeğin değişken ve göreceli olduğu görüşüne dayanır. Bu akıma göre, gerçeği olgu, yaşantı veya davranışlarla ilişkisini kanıtlayarak aramak gerekir (Erden, 1998).

$\mathrm{Bu}$ araştırmada, eğitime yön veren felsefi akımlar, Wiles ve Bondi (1993) tarafindan geliştirilen, Doğanay ve Sarı (2003) tarafından Türkçeye uyarlanan ve bu araştırmada da kullanılan "Felsefi Tercih Değerlendirme Ölçeği” (FTDÖ)'nde yer alan felsefi akımlar temel alınarak aşağıda kısaca açıklanmıştır. FTDÖ’nde yer alan felsefi akımlar; Daimicilik, İdealizm, Realizm, Deneyselcilik ve Varoluşçuluk'tur. 
Daimicilik, temelde idealizm ve realizme dayanmaktadır. Daimiciler, eğitimde evrensel ilkelere ve geleneğe vurgu yapmaktadır. Bu akıma göre eğitim, değişmez olana uyum sağlamaya yardım etmelidir. Çünkü hayatın, toplumun, insanın değişmeyen bazı gerçekleri vardır ve eğitim de kendisini bu gerçekler üzerine kurmalıdır. Bu bağlamda, eğitimin en temel amacı kalıcı değer ve fikirlerin aktarılmasıdır. (Arslan, 1998; Cevizci, 2010; Sönmez, 2002). Ayrıca, daimicilere göre insan doğasının en önemli yanı akıldır. Bu nedenle, eğitimde insan zihninin gelişmesine (entelektüel eğitime) önem verilmesi gerekir (Demirel, 2010).

İdealizm, maddi ve fiziki varlığı olmayan, duyularla algılanamayan, elle tutulup gözle görülemeyen şeylerin varlığını kabul etmeye dayanan ve maddeciliğin karşıtı olan bir felsefi akımdır. İdealizme göre insanın en önemli yönü ruhsal/zihinsel yönüdür. İdealist felsefeye göre eğitim, insan aklının ve insanın zihinsel yönünün geliştirilmesidir (Şişman, 2001). İdealist eğitimciler, düşünce ve kavramları birbirleriyle ilişkilendiren konu alanlarını tercih ederler. Onlara göre, en önemli konular ve en üst düzey bilgi biçimleri, kavramları birbiriyle bütünleştirip, aralarındaki ilişkileri ortaya koyanlardır (Erden, 1998).

Realizme göre var olan her şey gerçektir. Dış dünyanın insan algılarından bağımsız olduğu varsayımından hareket eden gerçekçilikte, maddenin varlığına olan inanç temeldir (Demirel, 2010). Realizme göre zihnimizdeki bilgiler bu dünyadan aldığımız duyumlara göre oluşmaktadır. Realizmin eğitim anlayışı, bu gerçekliğe öğrenciyi hazırlayacak, onun niteliğini anlayıp, onun için hareket edebilecek şekilde öğrenciyi yetiştirmeye dayanmaktadır (Büyükkaragöz ve diğ., 1998). Realist eğitimciler insan aklını merkez aldıklarından konu alanını sistematik olarak ayırarak organize etmenin düşünmeyi kolaylaştırdığını kabul eder (Erden, 1998).

Deneyselcilik özünü pragmatik felsefeden alır ve değişmeyi gerçeğin temeli olarak görür. Buna göre değişmez bir gerçeklikten söz edilemez. İnsan doğası da dahil olmak üzere her şey değişmektedir. Bu felsefi anlayışa göre eğitim, değişen çevre ve koşullara bağlı olarak insanı sürekli yeniden yetiştirme işidir. Aynı zamanda eğitim yaşama bir hazırlık değil yaşamın kendisidir. Eğitimde değişmez bir içerik söz konusu değildir. Eğitim, sürekli değişen çevre ve koşullara, insanın uyumunu sağlamaktır (Şişman, 2001). Deneyselciler, eğitimin özünü deneyimlerin sürekli olarak yeniden yapılandırılmasının oluşturduğuna inanırlar. Diğer taraftan, öğretimde hareket noktası öğrenenin gereksinimleridir. (Gutek, 2001: akt. Özbaş, 2015).

Varoluş̧̧uluk ise insanın özgürlüğüne önem veren ve her insanı kendine özgü benzersiz bir varlık olarak gören, esas itibariyle bireyselciliğe dayanan bir felsefi akımdır (Şişman, 2001). Varoluşçuluk, insanın - bir sosyal varlık olarak - toplum içinde ve insanlık ideali için eğitilmesine karşıdır. Varoluşçular, toplumsal kurumlara karşı oldukları için bireysel farklılıkların değerini bilirler ve grup öğretimine de karşıdırlar. Bu akıma göre, eğitim kişinin kendi kendini gerçekleştirmesinin bir vasıtasıdır (Ergün, 2003). Varoluşçuluğa göre, eğitimin hedeflerinden bazıları insanın kendi kendisini yaratmasını sağlama, özgür eylemde bulunma, seçme ve seçtiklerinden sorumlu olma, bilginin öznel olduğunu kabul etme, toplumsal değerlerden kurtulmadır (Sönmez, 2000).

Gerek felsefenin, gerekse eğitimin temelinde insan ve onun sorunlarıyla, bunların çözümleri yer almaktadır. Çeşitli felsefi akımların varlık, bilgi, değerler, ahlak, insan ve onun eğitimine ilişkin bakış açıları değişebilmektedir. Eğitimin amaçları, içeriği, öğretim yöntemleri de 
benimsenen felsefeye göre biçimlenmektedir (Şişman, 2001). Bununla birlikte felsefe bireysel olarak, kişisel inanç ve değerlerimizle ilgilenmemize, kim olduğumuzu, var olma nedenimizi ve bir ölçüde nereye gideceğimizi anlamamıza yardımcı olur (Demirel, 2010). Bu bağlamda, bireylerin benimsedikleri eğitim felsefelerinin bir bakıma onların düşünce tarzını, görüşlerini, inançlarını ve eğitim hedeflerini etkilediği; müzik eğitimi açısından ele alındığında ise, geleceğin müzik öğretmenlerinin müzik eğitimine yönelik görüşlerini, inançlarını, amaç ve hedeflerini benimsedikleri felsefi tercihlere dayalı olarak temellendirecekleri söylenebilir.

İlgili alan yazın incelendiğinde, eğitimin farklı alanlarında öğretmen adaylarının benimsedikleri eğitim felsefelerini saptamaya veya felsefi tercihlerinin çeşitli değişkenler açısından farklılaşıp farklılaşmadığına ilişkin araştırmaların olduğu görülmektedir (Livingston, Mcclain ve Despain 1995; Çoban, 2002; Duman, 2008; Gülten ve Karaduman, 2012; Biçer, Er ve Özel 2013). Ancak literatürde müzik eğitimi alanında öğrenim gören öğretmen adaylarının felsefi tercihlerini saptamaya yönelik bir araştırmaya rastlanmamıştır. Bu gerekçelerden yola çıkılarak gerçekleştirilen bu araştırmanın amacı; müzik öğretmeni adaylarının benimsedikleri eğitim felsefelerini saptamak ve çeşitli değişkenler açısından irdelemektir. Bu genel amaç doğrultusunda aşağıdaki sorulara cevap aranmıştır.

1. Müzik öğretmeni adaylarının benimsedikleri eğitim felsefeleri nedir?

2. Müzik öğretmeni adaylarının benimsedikleri eğitim felsefeleri cinsiyet, mezun olunan okul türü ve sınıf değişkenleri açısından farklılaşmakta mıdır?

\section{Yöntem}

\subsection{Araştırma modeli}

$\mathrm{Bu}$ araştırma betimsel yöntem çerçevesinde yürütülen bir tarama (survey) çalışmasıdır. Tarama yöntemi bir grubun belirli özelliklerini belirlemek için verilerin toplanmasını amaçlayan çalışmalardır (Büyüköztürk ve diğ., 2009).

\section{2. Çalışma grubu}

Araştırmanın çalışma grubunu 2015-2016 eğitim- öğretim yılında Muğla Sıtkı Koçman Üniversitesinde öğrenim gören ve araştırmaya gönüllü olarak katılan $(\mathrm{N}=107)$ müzik öğretmeni adayları oluşturmaktadır. Araştırmaya katılan müzik öğretmeni adaylarının 65 'i (\%60.7) kadın ve 42'si (\%39.3) erkektir. Müzik öğretmeni adaylarının 25'i (\%23.5) 1.sınıf, 28'i (\%26.2) 2.sınıf, 21'i (19.6) 3.sınıf ve 33’ü (30.8) 4.sınıf öğrencileridir. Adayların 92'si (\%86) Anadolu Güzel Sanatlar Lisesi (AGSL), 15'i (\%14) ise diğer lise türlerinden mezundur.

\subsection{Veri toplama araçları}

Araştırmada veri toplama aracı olarak Wiles ve Bondi (1993) tarafından geliştirilen Doğanay ve Sarı (2003) tarafından Türkçe' ye uyarlanan geçerlik ve güvenirlik çalışmaları yapılmış "Felsefi Tercih Değerlendirme Formu (FTDF)" (Philosophy Preference Assesment) kullanılmıştır. Form beşli likert tipidir ve 40 maddeden oluşmaktadır. Ölçeğin güvenirlik çalışmaları çerçevesinde Cronbach alfa değeri. 81 olarak bulunmuştur. Ölçeğin iki yarısının tutarlığını incelemek amacıyla yapılan test yarı test analizinde ise, ilk yarıya ait alfa değerinin. 63 ikinci yarıya ait alfa değerinin. 74 olduğu görülmüştür. Ölçeğin Guttman Split 
değeri ise. 74 olarak hesaplanmıştır. Bu araştırmada ölçeğin Cronbach alfa değerinin. 80 olduğu saptanmıştır. Bu değerler dikkate alındığında ölçeğin, müzik öğretmeni adaylarının benimsedikleri felsefi tercihlerini belirlemede kullanılabileceği söylenebilir. Ölçekteki 6,8 , $10,13,15,31,34$ ve 37 . maddeler daimicilik; 9, 11, 19, 21, 24, 27, 29 ve 33. maddeler idealizm; 4, 7, 12, 20, 22, 23, 26 ve 28 . maddeler realizm; 2, 3, 14, 17, 25, 35, 39 ve 40. maddeler deneyselcilik; 1, 5, 16, 30, 32, 36 ve 38. maddeler ise varoluşçu felsefeye ilişkindir (Doğanay, 2011).

Müzik öğretmeni adaylarının demografik özellikleri ile ilgili bilgi toplamak amacıyla araştırmacı tarafından geliştirilen Kişisel Bilgi Formunda cinsiyet, sınıf ve mezun olunan okul türü vb. ile ilgili sorular yer almaktadır. Kişisel bilgi formundan araştırma için gerekli görülenler seçilerek kullanılmıştır.

\subsection{Verilerin analizi}

Araştırmadan elde edilen veriler SPSS (sürüm 22,0) kullanılarak analiz edilmiş ve değerlendirilmiştir. Araştırmada belirlenen değişkenler yönünden müzik öğretmeni adaylarının demografik özelliklerini belirlemek amacıyla "frekans ve "yüzdelik" hesaplamalar yapılmış; eğitim felsefesine yönelik tercihlerinin dağılımına yönelik (\%) yüzde, standart sapma ve aritmetik ortalamalarına bakılmıştır. Müzik öğretmeni adaylarının Felsefi Tercih Değerlendirme Formundan aldıkları puanlar ile cinsiyet, sınıf ve mezun olunan okul türü puanları arasındaki farklılıkların belirlenmesi için ise, ilk aşamada Felsefi Tercih Değerlendirme Formundan aldıkları puanların normal dağılım özellikleri incelenmiştir. $\mathrm{Bu}$ amaçla, puanların çarpıklık-basıklık (skewness-kurtosis) ve Kolmogorov-Smirnov (K-S) değerlerine bakılmıştır.

Elde edilen sonuçlara göre değişkenler açısından; Daimicilik, .012 $(p<.05)$; İdealizm, .124, Realizm, $.004(p<.05)$; Deneyselcilik, $.001 \quad(p<.05)$ ve Varoluşçuluk $.018 \quad(p<.05)$ değerindedir. K-S testi sonuçları değerlendirildiğinde, idealizm felsefesinin puanlarının normal dağılımdan anlamlı (aşırı) sapma göstermediği; bunun yanında daimicilik, realizm, deneyselcilik ve varoluşçuluk felsefi akımlarının puan dağılımlarında normalden sapmaların anlamlı düzeyde olduğu belirlenmiştir. Bununla birlikte, çarpıklık ve basıklık katsayıları dikkate alındığında bütün puanların \pm 3 aralığında yer aldıkları tespit edilmiştir. Büyüköztürk (2007), çarpıklık ve basıklık değerlerinin \pm 1 aralığında yer almasının normallikten aşırı sapmalar olmaması şeklinde yorumlamaktadır. Ayrıca, Kalaycı (2008)'ya göre de katsayıların \pm 3 aralığında yer alması kabul edilebilir bir durumdur. Puanların çarpıklık-basıklık değerlerinin uç düzeylerde olmadığı ve normal dağılım eğrilerinde aşırı sapmalar olmadığı görüldüğü için parametrik istatistik tekniklerinin kullanılmasına karar verilmiştir.

$\mathrm{Bu}$ doğrultuda araştırmada, müzik öğretmeni adaylarının felsefi tercihlerinin cinsiyet ve mezun olunan okul türü değişkenleri açısından karşılaştırılmasına yönelik "İlişkisiz Grup t Testi”; sınıf değişkeni açısından felsefi tercihlerinin karşılaştırılmasına yönelik ise "Tek Faktörlü Varyans Analizi”'(One-Way Anova) kullanılmıştır.

\section{Bulgular}

Müzik öğretmeni adaylarının felsefi tercih puanlarına ilişkin ortalama ve standart sapma değerleri Tablo 1'de verilmiştir. 


\begin{tabular}{|c|c|c|c|}
\hline Eğitim Felsefeleri & $\mathrm{N}$ & $\overline{\mathrm{X}}$ & Ss \\
\hline Daimicilik & 107 & 26.69 & 4.85 \\
\hline İdealizm & 107 & 27.63 & 3.69 \\
\hline Realizm & 107 & 29.34 & 3.71 \\
\hline Deneyselcilik & 107 & 31.41 & 4.50 \\
\hline Varoluşçuluk & 107 & 26.85 & 3.93 \\
\hline
\end{tabular}

Tablo 1 incelendiğinde, müzik öğretmeni adaylarının felsefi tercih puanlarının ortalamalarına bakıldığında, Deneyselcilik $(\overline{\mathrm{x}}=31.41)$ en yüksek puanla ilk sirada tercih edilirken onu sırasıyla Realizm ( $\bar{x}=29.34)$, İdealizm $(\bar{x}=27.63)$, Varoluşçuluk $(\bar{x}=26.85)$ ve Daimicilik $(\bar{x}$ $=26.69)$ izlemektedir.

Tablo 2. Müzik öğretmeni adaylarının cinsiyet değişkenine göre "eğitim felsefesi tercihleri” için

\begin{tabular}{llllllll}
\multicolumn{7}{c}{ yapılan ilişkisiz grup “t” testi sonuçları } \\
\hline Eğitim & Cinsiyet & $\mathrm{N}$ & $\overline{\mathrm{x}}$ & $\mathrm{S}$ & $\mathrm{sd}$ & $\mathrm{t}$ & $\mathrm{p}$ \\
Felsefeleri & & & & & & & \\
\hline Daimicilik & Kadın & 65 & 26.97 & 4.38 & 105 & .735 & .464 \\
& Erkek & 42 & 26.26 & 5.53 & & & \\
İdealizm & Kadın & 65 & 27.71 & 3.77 & 105 & .251 & .802 \\
& Erkek & 42 & 27.52 & 3.59 & & & \\
Realizm & Kadın & 65 & 29.83 & 3.18 & 105 & 1.695 & .093 \\
& Erkek & 42 & 28.59 & 4.35 & & & \\
Deneyselcilik & Kadın & 65 & 31.57 & 3.82 & 105 & .450 & .653 \\
& Erkek & 42 & 31.17 & 5.43 & & & \\
Varoluşçuluk & Kadın & 65 & 26.77 & 3.79 & 105 & .265 & .792 \\
& Erkek & 42 & 26.98 & 4.18 & & & \\
\hline
\end{tabular}

Tablo 2'de görüldüğü gibi, müzik öğretmeni adaylarının felsefi tercih puanları cinsiyet değişkenine göre istatistiksel olarak birbirinden anlamlı bir şekilde farklılaşmamıştır.

\begin{tabular}{|c|c|c|c|c|c|c|c|c|}
\hline Eğitim & Okul & $\mathrm{N}$ & $\overline{\mathrm{X}}$ & $\mathrm{S}$ & $\mathrm{sd}$ & $\mathrm{t}$ & $\mathrm{p}$ & Cohen's d \\
\hline Felsefeleri & Türü & & & & & & & \\
\hline \multirow[t]{2}{*}{ Daimicilik } & AGSL & 92 & 27.18 & 4.63 & 105 & 2.679 & $.009 *$ & 0.52 \\
\hline & Diğer & 15 & 23.67 & 5.26 & & & & \\
\hline \multirow[t]{2}{*}{ İdealizm } & AGSL & 92 & 27.78 & 3.71 & 105 & .946 & .346 & - \\
\hline & Diğer & 15 & 26.80 & 3.57 & & & & \\
\hline \multirow[t]{2}{*}{ Realizm } & AGSL & 92 & 29.57 & 3.78 & 105 & 1.523 & .131 & - \\
\hline & Diğer & 15 & 28.00 & 3.07 & & & & \\
\hline \multirow[t]{2}{*}{ Deneyselcilik } & AGSL & 92 & 31.32 & 4.59 & 105 & .483 & .630 & - \\
\hline & Diğer & 15 & 31.93 & 4.03 & & & & \\
\hline \multirow[t]{2}{*}{ Varoluşçuluk } & AGSL & 92 & 26.70 & 3.85 & 105 & .937 & .351 & - \\
\hline & Diğer & 15 & 27.73 & 4.46 & & & & \\
\hline
\end{tabular}

Tablo 3'de görüldüğü gibi, mezun olunan okul türü değişkeni açısından müzik öğretmeni adaylarının puanları daimicilik değişkeni açısından anlamlı bir farklılık göstermektedir 
$\left[\mathrm{t}_{(105)}=2.679, \mathrm{p}<.05\right]$. Analiz sonuçlarına bakıldığında daimicilik felsefesine yönelik AGSL mezunlarının ortalamalarının $(\overline{\mathrm{X}}=27.18)$ diğer lise türlerinden mezun olan müzik öğretmen adaylarının ortalamalarına $(\bar{x}=23.67)$ göre daha yüksek olduğu; etki büyüklüğünün ise orta düzeyde [Cohen's $d>.05$ ]. olduğu görülmektedir Diğer felsefi akımlara yönelik ise mezun olunan okul türü değişkeni açısından anlamlı bir fark bulunamamıştır.

\begin{tabular}{|c|c|c|c|c|c|c|}
\hline $\begin{array}{c}\text { Eğitim } \\
\text { Felsefeleri }\end{array}$ & & $\begin{array}{l}\text { Kareler } \\
\text { Toplam1 }\end{array}$ & $\mathrm{sd}$ & $\begin{array}{c}\text { Kareler } \\
\text { Ortalamas1 }\end{array}$ & $\mathrm{F}$ & $\mathrm{p}$ \\
\hline \multirow[t]{3}{*}{ Daimicilik } & Gruplararas1 & 49.286 & 3 & 16.429 & .692 & .559 \\
\hline & Gruplariçi & 2445.536 & 103 & 23.743 & & \\
\hline & Toplam & 2494.822 & 106 & & & \\
\hline \multirow[t]{3}{*}{ İdealizm } & Gruplararas1 & 51.566 & 3 & 17.189 & 1.274 & .287 \\
\hline & Gruplariçi & 1389.219 & 103 & 13.488 & & \\
\hline & Toplam & 1440.785 & 106 & & & \\
\hline \multirow[t]{3}{*}{ Realizm } & Gruplararası & 70.872 & 3 & 23.624 & 1.749 & .162 \\
\hline & Gruplariçi & 1391.334 & 103 & 13.508 & & \\
\hline & Toplam & 1462.206 & 106 & & & \\
\hline \multirow[t]{3}{*}{ Deneyselcilik } & Gruplararas1 & 107.620 & 3 & 35.873 & 1.813 & .149 \\
\hline & Gruplariçi & 2038.286 & 103 & 19.789 & & \\
\hline & Toplam & 2145.907 & 106 & & & \\
\hline \multirow[t]{3}{*}{ Varoluşçuluk } & Gruplararası & 26.143 & 3 & 8.714 & .556 & .645 \\
\hline & Gruplariçi & 1613.464 & 103 & 15.665 & & \\
\hline & Toplam & 1639.607 & 106 & & & \\
\hline
\end{tabular}

Tablo 4'de görüldüğü gibi müzik öğretmeni adaylarının sınıf değişkenine göre eğitim felsefesi tercihleri için yapılan "Tek Faktörlü Anova" sonuçlarına göre istatistiksel açıdan anlamlı bir fark bulunamamış; sınıf değişkeni açısından müzik öğretmeni adaylarının eğitim felsefesi tercih puanları birbirinden farklılaşmamıştır.

\section{Tartışma}

Araştırma sonuçlarına göre, müzik öğretmeni adaylarının en çok tercih ettikleri eğitim felsefesinin Deneyselcilik ( $\bar{x}=31.41)$ olduğu, deneyselciliği sırası ile Realizm $(\bar{x}=29.34)$ İdealizm ( $\bar{x}=27.63)$ Varoluşçuluk $(\bar{x}=26.85)$ ve Daimicilik $(\bar{x}=26.69)$ felsefesinin izlediğ $i$ belirlenmiştir. İlgili literatür incelendiğinde bu araştırmadan elde edilen sonuçları destekleyen ve bu sonuçlarla benzerlik gösteren pek çok araştırmaya rastlanmaktadır. Örneğin; Livingston, Mcclain ve Despain (1995), üniversite mezunu öğrencilerin benimsedikleri eğitim felsefeleri ve eğitim hedefleri arasındaki tutarlılığı incelediği araştırmasında; mezun öğrencilerin, büyük çoğunluğunun deneyselcilik akımını benimsediğini saptamıştır. Bunun yanında Çoban (2002) sınıf öğretmenliği bölümünde okuyan öğretmen adaylarının eğitim sürecine ilişkin felsefi tercihlerine yönelik gerçekleştirdiği çalışmasının sonucunda öğretmen adaylarının deneyselcilik felsefesini daha fazla tercih ettiklerini saptamıştır. Benzer bir çalışmada yine Çoban (2004) sınıf öğretmenlerinin eğitim sürecine ilişkin felsefi tercihlerini değerlendirmeye ilişkin bir araştırma yapmış ve aritmetik ortalamalar açısından sınıf öğretmenlerinin de yine çoğunlukla deneyselcilik felsefesini tercih ettiklerini belirtmiştir. 
Diğer taraftan, Doğanay ve Sarı'da (2003) ilköğretim öğretmenlerinin sahip oldukları eğitim felsefelerine ilişkin algılarını değerlendirmeye yönelik gerçekleştirdikleri araştırmalarında, öğretmenlerin kendi eğitim felsefelerini en yüksek oranda deneyselcilik olarak algıladıklarını saptamıştır. Öğretmen adaylarına yönelik gerçekleştirilen diğer bir araştırma da Duman (2008), felsefi tercih sıralamasında Muğla Sitkı Koçman Üniversitesi Eğitim Fakültesi öğrencilerinin büyük bir çoğunluğunun öncelikli olarak deneyselcilik akımını benimsediğini saptamıştır.

Bu çalışmalara ek olarak Gülten ve Karaduman (2012) araştırmasında öğretmen adaylarının en çok tercih ettikleri eğitim felsefesini deneyselcilik en az tercih ettikleri eğitim felsefesini ise varoluş̧̧uluk olarak saptanmıştır. Yapıcı (2013) da, öğretmen ve öğretmen adaylarının eğitim felsefelerini belirlemeye yönelik gerçekleştirdiği araştırmasında ilköğretim öğretmenleri ve öğretmen adaylarının, akımlara ilişkin görüşlerinde en yüksek aritmetik ortalamanın deneyselcilik akımında olduğunu saptamıştır. Eğitimin farklı alanlarında öğretmen adaylarının felsefi tercihlerine yönelik gerçekleştirilen diğer çalışmalarda da felsefi bakış açılarının yüksek oranda deneyselcilik akımında yoğunlaştığı görülmektedir ( Doğanay, 2011; Aslan, 2014; Şahin, Tunca ve Ulubey 2014; Özbaş, 2015).

Yukarıdaki araştırmalardan elde edilen sonuçlar bu araştırman da elde edilen sonuçlarla paralellik göstermektedir. Sonuç olarak, müzik öğretmeni adaylarının eğitim felsefesi tercihlerinin en çok deneyselcilik $(\bar{x}=31.41)$ akımında yoğunlaşması, eğitim süreçlerinde daha çok etkinliğe dayalı ve öğrenci merkezli bir yaklaşımı benimsedikleri şeklinde yorumlanabilir. Nitekim, günümüzde eğitim de öğrenme ve öğretmeye ilişkin yeni değerler öğrenmenin öğrenci merkezli olarak yeniden düzenlenmesini öngörmektedir. Bu değerlere göre, vurgu bilginin aktarılmasında değil öğrencidedir. Bilgi edinme değil, bilgiyi kullanma ve ondan yeni bilgi üretme önemlidir. Bunun için öğretmenin "bilgi aktaran konumundan, öğretirken öğrenen bir konuma” geçmesi gerekmektedir (Özden,2005).

Bunun yanında müzik öğretmeni adaylarının deneyselcilik akımından sonra en çok tercih ettikleri felsefi akımın realizm $(\bar{x}=29.34)$ ve idealizm $(\bar{x}=27.63)$ olduğu görülmektedir. Diğer taraftan varoluşçuluk $(\bar{x}=26.85)$ ve daimicilik $(\bar{x}=26.69)$ akımlarının ortalamaları dikkate alındığında ise bu iki akımın tercih puanlarının birbirine çok yakın olduğu göze çarpmaktadır. Yapıcı (2013)'da araştırmasında, öğretmen ve öğretmen adaylarının felsefi tercih puanlarının ortalamalarının birbirine çok yakın olduğu sonucuna ulaşmış ve Wiles ve Bondi (1989)'nin önerdiği Pattern 5.'e atıf yaparak; ya bir eklektik felsefeye sahip oldukları ya da kendi şahsi felsefelerini oluşturamamış veya oluşturmaya yeni başlamış olduklarını ileri sürmüştür. $\mathrm{Bu}$ araştırmada da, çağdaş eğitim felsefesi çerçevesinde değerlendirilen varoluşçuluk akımının puanları ile geleneksel eğitim felsefesi çerçevesinde değerlendirilen daimicilik akımı puanlarının birbirine çok yakın olması, müzik öğretmeni adaylarının da henüz şahsi felsefelerini oluşturamamış olduğu veya felsefi tercih yapmada eklektik bir anlayışı benimsedikleri şeklinde yorumlanabilir.

Araştırmada cinsiyet değişkeni açısından müzik öğretmeni adaylarının felsefi tercih puanlarında istatistiksel olarak anlamlı bir farklılık bulunamamıştır. Araştırmadan elde edilen bu sonuç, Çoban (2002)'ın; Doğanay (2011)'ın; Gülten ve Karaduman (2012)'ın; Biçer, Er ve Özel (2013)'in ve Özbaş (2015)'ın, öğretmen adaylarının felsefi tercihlerine yönelik gerçekleştirdikleri araştırmalardan elde ettikleri sonuçları destekler niteliktedir. $\mathrm{Bu}$ 
araştırmadan da elde edilen sonuçlara dayanarak eğitim felsefesi tercihi üzerinde cinsiyetin önemli bir etkisinin olmadığı söylenebilir.

Mezun olunan okul türü açısından elde edilen sonuçlara bakıldığında, müzik öğretmeni adaylarının felsefi tercihlerine yönelik; idealizm, realizm, deneyselcilik, varoluşçuluk puanlarında anlamlı bir farklılık bulunamamıştır. Bununla birlikte müzik öğretmeni adaylarının puanları daimicilik boyutunda anlamlı bir farklılık göstermiştir $(\mathrm{p}<.05)$. Ortalamalar bakıldığında AGSL mezunlarının ortalamalarının $(\overline{\mathrm{x}}=27.18)$ diğer lise türlerinden mezun olan müzik öğretmen adaylarının ortalamalarına $(\bar{x}=23.67)$ göre daha yüksek olduğu görülmektedir. Bu sonuç, AGSL mezunu müzik öğretmeni adaylarının diğer lise türlerinden mezun olan müzik öğretmeni adaylarına göre eğitim durumlarında geleneksel felsefi yaklaşımları çerçevesinde öğretmen merkezli bir anlayışı daha çok benimsedikleri şeklinde yorumlanabilir.

Sınıf değişkeni açısından elde edilen sonuçlara bakıldığında ise müzik öğretmeni adaylarının sınıf değişkenine göre eğitim felsefesi tercih puanları birbirinden anlamlı bir şekilde farklılaşmamıştır. İlgili literatür incelendiğinde; bu araştırmadan elde edilen sonuçlardan farklı olarak, Biçer, Er ve Özel (2013) araştırmalarında sınıf değişkeni açısından öğretmen adaylarının benimsedikleri eğitim felsefelerinde anlamlı bir farklılık saptamışlardır. Araştırma sonucunda, öğretmen adaylarının üniversitenin ilk yıllarında daimicilik felsefesini benimsediği; son yıllara gelindiğinde bu felsefeye olan inançlarında azalma olduğu belirtilmiştir. Bu çalışmaya ek olarak Şahin, Tunca ve Ulubey (2014) öğretmen adaylarının eğitim inançlarına yönelik gerçekleştirdikleri çalışmalarında, genel olarak öğretmen adaylarının puanlarının sınıf düzeyine göre farklılaştığını; daimicilik alt faktöründe alt sınıfların ortalamalarının üst sınıflardan yüksek olduğunu, ilerlemecilik, yeniden kurmacılık ve varoluşçuluk alt faktörlerinde ise üst sınıf ortalamalarının alt sınıflardan yüksek olduğunu belirlemişlerdir. Biçer, Er ve Özel (2013)'in ve Şahin, Tunca ve Ulubey (2014)'in sınıf değişkeni açısından elde ettikleri sonuçların bu araştırmadan farklı olmasının nedeni her iki araştırmada da öğretmen adaylarının felsefi tercihlerini belirmeye yönelik farklı ölçme araçlarının kullanılması olabilir. Ya da bu araştırmadan elde edilen sonuçlara dayanarak, sınıf değişkeninin öğretmen adaylarının benimsedikleri eğitim felsefesi tercihleri üzerindeki etkisinin değişkenlik göstereceği söylenebilir.

Araştırmadan elde edilen sonuçlara dayanarak aşağıdaki öneriler getirilmiştir: Müzik öğretmenliği lisans programı çerçevesinde müzik öğretmeni adayları 1. Yarıyılda "Felsefe" dersi almaktadırlar (Yüksek Öğretim Kurumu,2007). Ancak araştırmadan elde edilen sonuçlar dikkate alındığında, müzik öğretmeni adaylarının eğitim felsefesine yönelik tercihlerinde çağdaş eğitim felsefesi kapsamında değerlendirilen varoluşçuluk akımının puan ortalamaları ile geleneksel eğitim felsefesi kapsamında değerlendirilen daimicilik akımının puan ortalamalarının birbirine çok yakın olması - Yapıcı (2013)'nın da araştırmasında ilköğretim öğretmen adayları için belirttiği gibi- eklektik felsefeye sahip oldukları ya da henüz kendilerine has bir eğitim felsefesi oluşturamadıklarını düşündürmektedir. $\mathrm{Bu}$ doğrultuda, müzik öğretmeni adaylarının eğitim felsefesine ilişkin bakış açılarının geliştirilmesine ve eğitim felsefesine yönelik daha çok farkındalık kazanabilmelerine olanak sağlayacak ve müzik eğitimleri sürecindeki inançlarını, amaç ve hedeflerini buna göre düzenleyebilmelerine katkıda bulunabilecek eğitim ortamları yaratılabilir. 
Bundan sonraki yapılacak araştırmalarda daha zengin ve derinlemesine veri elde etmek için müzik öğretmeni adaylarının benimsedikleri eğitim felsefeleri hem nicel hem de nitel yöntemler kullanılarak belirlenebilir. Buna ek olarak daha genellenebilir sonuçlara ulaşılması için daha büyük çalışma grupları üzerinde araştırmalar yapılabilir.

\section{Kaynakça}

Arslan, A.(1998). Felsefeye giriş. Ankara: Vadi Yayınları.

Aslan, Ö. M. (2014). Eğitim felsefesi dersinin okul öncesi öğretmen adaylarının felsefi tercihlerine ve eleştirel pedagojiye yönelik görüşlerine olan etkisi. Elektronik Sosyal Bilimler Dergisi, 13(48): 1-14.

Biçer, B., Er, H. ve Özel, A. (2013). Öğretmen adaylarının epistemolojik inançları ve benimsedikleri eğitim felsefeleri arasındaki ilişki. Ĕgitimde Kuram ve Uygulama, 9(3): 229-242.

Brauner, C. J. ve Burns, H. W. (1965). Eğitim felsefesi. S. Büyükdüvenci (Çev.) http://dergiler.ankara.edu.tr/dergiler/40/512/6313.pdf . Erişim: 28.09.2015

Büyükdüvenci, S. (1987). Eğitim felsefesi: Yazılar. Ankara: Yargıcığlu Matbaası.

Büyükkaragöz, S. Ş., Muşta, M. C., Yılmaz, H. ve Pilten, Ö. (1998). Öğretmenlik mesleğine giriş. Konya: Mikro Yayınları.

Büyüköztürk, Ş. (2007). Veri analizi el kitabı. Ankara: Pegem Yayıncılık.

Büyüköztürk, Ş., Çakmak, E. K., Akgün, Ö. E., Karadeniz, Ş. ve Demirel, F. (2009). Bilimsel araştırma yöntemleri (4. Baskı). Ankara: Pegem Akademi.

Cevizci, A. (2010). Ĕgitim felsefesi (2. Baskı) Ankara: Say Yayınları.

Çoban, A. (2002). Sınıf öğretmenliği öğretmen adaylarının, eğitim sürecine ilişkin felsefi tercihlerinin değerlendirilmesi. Cumhuriyet Üniversitesi Sosyal Bilimler Dergisi.26(2): 311-318.

Çoban, A. (2004). Sınıf öğretmenlerinin eğitim sürecine ilişkin felsefi tercihlerinin değerlendirilmesi. XIII. Ulusal Eğitim Bilimleri Kurultayı, 6-9 Temmuz 2004. İnönü Üniversitesi, Eğitim Fakültesi, Malatya.

Demirel, Ö. (2010). Eğitimde program gelişstirme (10. baskı). Ankara: Pegem Yayınc1lık.

Doğanay, A. (2011). Hizmet öncesi öğretmen eğitiminin öğretmen adaylarının felsefi bakış açılarına etkisi. Eğitim ve Bilim, 36(161): 332-348.

Doğanay, A. ve Sarı, M. (2003), İlköğretim Öğretmenlerinin Sahip Oldukları Eğitim Felsefelerine İliş̧kin Algıların Değerlendirilmesi, "Öğretmenlerin Eğitim Felsefeleri”, Türk Eğitim Bilimleri Dergisi, 1(3) : 321-337.

Duman, B. (2008). Öğrencilerin benimsedikleri eğitim felsefeleriyle kullanıldıkları öğrenme strateji ve öğrenme stillerinin karşılaştırılması. Çanakkale Üniversitesi Sosyal Bilimler Enstitüsü Dergisi, 1(17): 203-224.

Erden, M. (1998). Öğretmenlik mesleğine giriş. İstanbul: Alkım Yayınları.

Ergün, M. (2003). Eğitimin felsefi temelleri. Ç. Özdemir (Ed). Öğretmenlik Mesleğine Giriş (69-99). Ankara: Asil Yayıncilik.

Ergün, M. (2014). Eğitim felsefesi (4. Baskı). Pegem Yayınc1lık: Ankara.

Gülten, D. Ç. ve Karaduman, G. B. (2012). The evaluation on the prospective primary teachers' philosophical preferences about educational process. US-China Education Review A (3): 345-350.

Karslı, M. D. (2007). Eğitim bilimine giriş. Ankara: Pegem Yayıncılık. 
Kalaycı, Ş. (2008). SPSS uygulamalı çok değişkenli istatistik teknikleri. Ankara: Asil Yayıncilik.

Kaygısız, İ. (1997). Eğitim felsefesi ve Türk eğitim sisteminin felsefi temelleri. Erişim tarihi: 05.11 .2015 http://felsefe.kku.edu.tr/belgeler/ders/egitim_felsefesi/egitim_felsefesi_akimlari.pdf.

Livingston, M. J., Mcclain, B. R. M. ve Despain, B. C. (1995). Assessing the consistency between teachers' philosophies and educational goals. Education, 116: 124-129.

Özbaş, B. Ç. (2015). Sosyal bilgiler öğretmen adaylarının felsefi bakış açılarının öğretmenlik eğitimi sürecinde incelenmesi. TSA Dergisi, 19(1): 117-138.

Özden, Y. (2005). Eğitimde yeni değerler (6.bask1). Ankara: Pegem Yayıncılık.

Sönmez, V. (2000). Eğitimin felsefi temelleri. V. Sönmez (Ed.) Öğretmenlik mesleğine giriş (33-58). Ankara: Anı Yayıncılık.

Sönmez, V. (2002). Eğitim felsefesi. Ankara: Anı Yayıncılık

Şahin, S. A., Tunca, N. ve Ulubey, Ö. (2014). Öğretmen adaylarının eğitim inançları ile eleştirel düşünme eğilimleri arasındaki ilişki. Illköğretim Online, 13(4): 1473-1492.

Şişman, M. (2001). Öğretmenliğe giriş (3.baskı). Ankara: Pegem Yayıncılık.

Timuçin, A.(2005). Felsefeye giriş. İstanbul: Bulut Yayınları.

Yapıc1, Ş. (2014). Öğretmen ve öğretmen adaylarının eğitim felsefeleri. International Periodical For The Languages, Literature and History of Turkish or Turkic 8(8): 1431-1452.

Yılmaz, K., Altınkurt, Y. ve Çokluk, Ö. (2011). Eğitim inançları ölçeği’nin geliştirilmesi: Geçerlik ve güvenirlik çalışması. Kuram ve Uygulamada Eğitim Bilimleri, 11(1): 335-350.

YÖK. (2007). Eğitim fakültesi ögrretmen yetiştirme lisans programları. Erişim tarihi: 04.11.2015. https://www.yok.gov.tr/documents/10279/30217/. 